\title{
PERSPEKTIF KAREN ARMSTRONG TENTANG ISLAMOFOBIA DI MEDIA BARAT
}

\author{
Rio Febriannur Rachman \\ Institut Agama Islam Syarifuddin Lumajang \\ Email : riofrachman21@gmail.com
}

\begin{abstract}
Islamophobia written by Karen Armstrong, John L. Esposito, Imam Abdul Malik Mujahid, et al (published by Mizan in 2018) explains how Islamophobia still afflicts some groups, including Westerners (Americans and Europeans). The causes are the materialization of the phenomenon of terrorism, ISIS, and wahabism which are considered as radical. Such representations are established by the mass media. The definition of Islam in the Western media is closely related to the distortion of meaning, sentiment and stigma. Though, some write objective defense for Islam.
\end{abstract}

Keywords: Islamophobia, Distortion of Meanings, Sentiment and Stigma, Defense

\section{PENDAHULUAN}

Dalam buku berjudul Islamofobia yang ditulis oleh Karen Armstrong, John L. Esposito, Imam Abdul Malik Mujahid, dkk (diterbitkan Mizan, 2018), dijelaskan tentang bagaimana Islamofobia masih menjangkiti sebagian kalangan, termasuk kalangan Barat (Amerika dan Eropa).Salah satu penyebabnya, adalah kemunculan representasi Islam yang keras melalui fenomena terorisme, ISIS, dan wahabisme yang dianggap sebagian orang sebagai radikalisme. Sumber pengetahuan representasi tersebut, tentu saja media massa.

Media massaberada di tengah realitas sosial yang sarat dengan berbagai kepentingan, konflik, dan fakta yang kompleks serta beragam. Eriyanto (2005) menjelaskan bahwa menurut pandangan kritis, media adalah alat kelompok yang memiliki dominasi untuk memanipulasi dan mengukuhkan kehadirannya sambil memarjinalkan kelompok yang tidak dominan.

Media massajuga memiliki sejumlah fungsi salah satunya cultural transmission. Terkait dengan fungsi ini, Walter Lippman (1998) dengan dalil populernya world outside and pictures in our heads, berpendapat bahwa media berfungsi sebagai pembentuk makna.Lalu, melalui interpretasinya mengenai berbagai peristiwa secara 
radikal dapat mengubah interpretasi orang tentang suatu realitas dan pola tindakan mereka.Artinya, pandangan terhadap realita ditampilkan oleh media dengan caracara tertentu.Konseptualisasi fenomena mediasi melalui fungsi transmisi budaya dari Lippman itu sendiri, dalam terminologi pengetahuan dikenal dengan konsep representasi (Mudjianto, 2011).

Ida (2011) menjelaskan, representasi adalah salah satu proses memproduksi kebudayaan. Proses pemaknaan terjadi dalam konteks tertentu yang dipengaruhi oleh latar belakang kebudayaan masyarakat tertentu. Akan ada makna khusus dalam kondisi dan konteks tertentu itu.

Representasi menerangkan makna akan sesuatu melalui sesuatu yang lain. Dalam kaitan penelitian film, hal yang ingin dijelaskan itu digambarkan atau diwakilkan oleh gambar visual.Menurut Hall (1997), representasi adalah produksi makna dari konsep yang ada di benak manusia melalui bahasa atau teks.

Edward W. Said dalam bukunya berjudul Orientalisme pada sub babJejak-Jejak Orientalisme di bagian Representasi Islam ${ }^{1}$ menerangkan, media Barat, dalam hal ini Eropa dan Amerika, kerap merepresentasikan Islam dengan acuannya sendiri. Umumnya, yang terjadi adalah hegemoni. Ada pun sisi yang biasa dilihat oleh media barat itu adalah: pertama, Islam dan kekerasan; kedua, Islam dan perdamaian; ketiga, Islam dan sifat lemah.

Kita tentu tidak pernah membayangkan berata besarnya kerusakan yang telah ditimbulkan oleh mitos yang berasal dari orientalisme abad XX tersebut.Mitos itu telah menciptakan potret orang Arab (Islam, pen) sebagai orang yang kasar dan beringasan, seperti yang banyak diasumsikan oleh masyarakat kuassi-Barat yang "maju”. (Edward Said: 2010)

Apa yang disampaikan oleh Said mengacu pada kekerasan dan kekasaran yang dilakukan oleh orang Islamdalam representasi yang tersaji di media. Padahal, wacana di luar media tidak sepenuhnya demikian.Islam bukan agama yang identik dengan kekerasan.Peperangan yang terjadi di masa penaklukan pada awal

'Said, Edward W (2010), Orientalisme, Yogyakarta: Pustaka Pelajar.Alih bahasa, Achmad Fawaid. Terjemahan dari buku Orientalism (1978), New York: Vintage Books. 
kelahirannya, adalah langkah terakhir yang jika itu tidak diambil, resikonya adalah kemusnahan Islam sendiri.

Jika dunia Islam sering melakukan ekspansi terutama melalui penaklukan militer yang dilakukan di bawah bendera jihad (perjuangan), haruskah kemudian menyimpulkan bahwa Islam adalah "agama pedang"?Tidak tepat.Penaklukan memperluas kekuasaan politik umat Islam, sekadar memastikan, tapi masyarakat yang ditaklukkan tidak dipaksa untuk masuk Islam, dan banyak dari mereka mempertahankan agama mereka. (Mustafa Akyol, 2014)

Pada masa awal peradaban Islam, berperang dan menyerang adalah teknik ofensif untuk menghindari ancaman diserang terlebih dahulu.Demikianlah bahasa zaman di waktu itu.Tidak lantas bahasa itu dapat diartikulasikan senada di masa sekarang.Sebab, secara prinsip Islam tidak mengajarkan kekerasan apalagi pemaksaan.

Dalam teori hubungan internasional saat ini, situasi itu digambarkan sebagai realisme ekstrem yakni situasi di mana antar kekuatan saling berebut kekuasaan secara fulgar menggunakan kekuatan mentah.Sikap diam adalah ancaman sedangkan sifat agresif adalah keniscayaan zaman².

Sementara itu, media Barat juga kerap memotret gejala keengganan Islam untuk berdamai dan menjaga ketentraman.Islam tak hanya digambarkan sebagai mereka yang keras dan kasar.Namun juga, sebagai pihak yang tak suka melakukan perdamaian.Said menyampaikan, media di luar Islam kadang kala menggambarkan Islam dengan representasi yang tidak fair.

Alroy berusaha membuktikan bahwa karena orang-orang Arab: 1) bersatu dalam kecenderungan mereka untuk membalas dendam, 2) secara psikologis tidak mampu untuk bersikap damai dan 3) memiliki pembawaan yang terikat pada suatu konsep keadilan yang sesungguhnya bertentangan dengan keadilan itu, maka mereka tidak

2 Burdah, Ibnu (2014), Islam Kontemporer, Revoluasi dan Demokrasi, Malang: Intrans Publishing 
boleh dipercaya dan harus terus-menerus diperangi, sebagaimana kita memerangi penyakit berbahaya ${ }^{3}$.

Said (2010) menjelaskan, orang-orang Arab memang sering direpresentasikan sebagai pihak yang memuja kekuasaan dan keberhasilan.Termasuk kekayaan.Orang Islam digambarkan sebagai mereka yang lemah dalam memegang prinsip.

Said mengutip Sania Hamady yang menuliskan bahwa orang-orang Islam lemah dalam mempertahankan persatuan.Mereka mampu mengalami ledakanledakan kelompok.Akan tetapi, tidak tekun dan sabar dalam memelihara upaya kelompok tersebut. Mereka juga gampang ditekan dan dipaksa oleh orang-rang Barat dalam hal ini Amerika dan Eropa ${ }^{4}$.

Media barat mungkin tidak pernah secara tegas mengatakan jika ada “perang" antara barat dan orang Islam.Tapi pada kenyataannya, Amerika Serikat yang menjadi salah satu representasi barat selalu berada dalam pusaran konflik terhadap Islam.Seusai serangan teroris 11 September 2001 yang mengguncang Amerika Serikat, misalnya.Konflik semakin meruncing dengan berbagai pernyataan yang berkembang di media barat.

\section{PEMBAHASAN}

\section{Distorsi Makna}

Penelitian tentang Islam dan atau muslim di media sudah banyak dilakukan. Antara lain, karya Driss Ridouani pada 2011. Dia membuat penelitian berjudul The Representation of Arabs and Muslims in Western Media (Barcelona: Revista Universitaria de Treballs Academics). Karya ini lebih banyak berisi opini tentang distorsi definisi Islam dan muslimyang tercantum di banyak media.

Apa yang dituliskan oleh Ridouani menegaskan bahwa redefinisi wacana Islam dan muslim sudah terjadi sejak puluhan tahun lalu. Bahkan, lukisan-lukisan yang mendeskreditkan Islam sudah lahir lebih dari seratus tahun lalu.Penelitian Ridouani terkesan subjektif karena kebanyakan pernyataan adalah tuangan komentar

\footnotetext{
${ }^{3}$ Said, Edward W (2010), Orientalisme, Yogyakarta: Pustaka Pelajar.Alih bahasa, Achmad Fawaid. Terjemahan dari buku Orientalism (1978), New York: Vintage Books. ${ }^{4}$ Ibid.
} 
penulisnya. Bahwa Islam, menurut Ridouani, bukanlah seperti yang banyak terlihat di media-media eropa dan Amerika (baca: barat).

Artikel jurnal lain yang ditulis Rubina Ramji (University of Ottawa) berjudul From Navy Seals to The Siege: Getting to Know the Muslim Terrorist, Hollywood Style juga pernah menyinggung soal wacana Islam di media, khususnya di film Amerika Serikat atau Hollywood. Penelitian ini diterbitkan The Journal of Religion and Film. Ramji membedah bagaimana Islam dan muslimdigambarkan melalui film-film Hollywood. Baik yang memberi gambaran baik, maupun yang tidak baik (teroris dan bengis).Ramji menjelaskan satu demi satu film berdasar gambaran Islam yang ditampilkan.Ada yang baik, ada pula yang buruk.

\section{Sentimen dan Stigma}

Beragam pernyataan silih berganti mengisi ruang pemberitaan. Misalnya, yang menyebutkan bahwa Nabi Muhammad mengajarkan kekerasan dan merupakan seorang yang sakit jiwa. Kecaman yang terlontar juga menghujam pada Islam sebagai agama. Bukan lagi mengkritisi orang Islam sebagai pelaku.

Rod Parsley, penulis buku Silent No More (2005), dengan tegas menyebutkan Islam sebagai agama yang anti kristen. Sedangkan John Hagee, pendiri Christian United for Israel (CUFI), terang-terangan mengatakan kalau AS sedang dalam perang terhadap Islam.

Anouar Majid (2012) menjelaskan, anggapan terhadap Islam yang keras, kasar, dan tidak memiliki toleransi tak jarang mengemuka. Dalam bukunya berjudul Islam and America, dia mengutip sejumlah kejadian maupun fenomena anti Islam yang digaungkan pula melalui media barat.

Franklin Graham is famous for saying that Islam is " a very evil and wicked religion," Pat Robertson for describing Mohammed as "an absolute wild eyed fanatic. A robber. A brigand. A killer. And John Farwell for Calling the Muslim prophet a "terrorist" on national television. (Anouar Majid, 2012)

Franklin Grahamterkenal denganhujatannya yang menyatakanıslam sebagaiagama yang sangatjahat, Sementara Pat Robert son 
menggambarkan Muhammad sebagai seorang fanatic bermata liar jelalatan. Seorang perampok. Seorang pembunuh. Sedangkan John Farwell menyebut nabi orang Islam sebagai teroris pada sebuah acara di televisi nasional

Cotton Mather, pendeta dari Massachusetts, menambah deretan celaan pada Nabi Muhammad dengan menghujatnya sebagai seorang kasar dan nabi nan tolol juga licik. Seorang pemimpin baptis dari Rhode Island bernama Roger Williams, bahkan menjulukinya sebagai nabi yang memiliki kemampuan tipu daya menakjubkan. Islam, kata Williams, adalah agama yang penuh dengan sensualitas, deceit, despotism, and Ignorance terhadap golongan yang lain.

Jerry Vinces, mantan presiden Southern Baptist Convention, lain lagi. Dia memakai sudut pandang pedofilia dalam memandang Nabi Muhammad. Dia menyebutkan, oleh karena Nabi Muhammad menikahi Aisyah pada usia enam atau sembilan tahun, maka dapat dipastikan laki-laki itu tengah melakukan kekerasan seksual pada anak kecil.

Pada musim panas 2010 lalu, saat ada rencana untuk membangun Islamic Center di dekat Ground Zero Manhattan, Terry Jones, seseorang yang mengklaim dirinya sebagai pastur dari gereja di Gainseville, Florida, mendeklarasikan rencna perayaan “International Burn the Quran Day". Dalam tayangan telivisi di kanal CNN, dia mengatakan, Islam dalah Iblis yang menyebabkan miliaran orang masuk neraka. Islam adalah agama yang penuh kekerasan dan itu terbukti berkali-kali.

Berkaca pada masa lampau, tambah Majid (2012), sebagian orang Amerika masih beranggapan bahwa Islam adalah agama yang tirani. Meskipun Islam saat ini berupaya menghilangkan pandangan itu, namun orang-orang kristiani dan sekuler di AS masih kerap mengacu pada sejarah yang menunjukkan bahwa penyebaran Islam dilaakukan dengan peprangan atau pertumpahan darah. Perang yang terjadi di kisaran abad 14 dan 15 antara kristen Eropa dan Islam makin menegaskan pandangan tersebut. Sebagian orang Kristen di Amerika Serikat bahkan secara gamblang berpandangan, perang antara Islam dan Barat tak mungkin berakhir. Karena sejak mula sudah termaktub di kitab Injil. 


\section{Pembelaan}

Dari namanya, Islam adalah agama keselamatan. Pemeluknya, muslim, adalah orang yang berserah diri pada Tuhan. Kaum muslimin (jamak dari muslim) diajarkan untuk saling menebar doa keselamatan tiap berjumpa.Dengan ucapan, “Assalamualaikum” atau semoga keselamatan menyertaimu.

Tidak hanya pada sesama muslim, Islam menggariskan para pemeluknya untuk menjadi penebar kebahagian bagi alam semesta (rahmatan lil alamin). Faktanya, sebagian kalangan dari dunia Barat, Amerika dan Eropa, dan sebagian kalangan lain yang biasanya tidak memahami Islam secara baik, memandang Islam tidak secara holistik.

Sebagian dari mereka mengalami Islamofobia atau ketakutan terhadap Islam.Penyebabnya antara lain, seperti disampaikan oleh Karen Armstrong (2018, 22), karena tumbuhnya gerakan radikal seperti ISIS dan sebangsanya, yang bersumber dari pemikiran Wahabisme.Mereka menunjukkan laku beringas di muka bumi dan seolah-olah menjelma cermin representasi umat Islam.Masyarakat Indonesia, khususnya kaum muslimin, memiliki tanggungjawab untuk menjaga negeri ini, dari pengaruh Wahabisme yang saklek dan eksklusif.Bibit-bibit Wahabisme mesti diwaspadai karena potensial melahirkan gerakan-gerakan radikal yang kontra produktif bahkan dekonstruktif.

Aktifisme gerakan sosial politik transnasional juga harus diawasi secara optimal, khususnya oleh pemerintah. Sebab, mereka yang di Indonesia ini berpola organisasi atau pekumpulan, tidak memiliki akar kenusantaraan dan nasionalisme yang dalam. Kecintaan mereka terhadap kemajemukan masih perlu dipertanyakan karena mereka tidak lahir di tanah air ini.

Yang harus dilakukan bukanlah melakukan pemberantasan atau genosida pada masyarakat yang terlanjur terjebak. Justru, orang-orang yang sudah terlanjur nyemplung di sana, khususnya yang berkewarganegaraan Indonesia, perlu dirangkul dan diajak berdiskusi konstruktif.

Islam adalah agama yang damai dan tidak menginginkan pertikaian.Apalagi, terbukti kalau Islam memiliki percepatan penyebaran yang tinggi di Amerika Serikat dan Eropa (Armstrong, 2018, 53).Kalau memang Islam ditebarkan dengan semangat Volume 4, Nomor 2, Agustus 2018| 288 
kebencian dan penyerangan atau invasi yang tidak sesuai dengan akal budi manusia, mustahil perkembangan agama samawi terakhir ini bisa gencar seperti sekarang.

Aksi-aksi terorisme yang mengatasnamakan Islam jelas sudah terlepas dari nilai-nilai keislaman. Terorisme menjadi salah satu objek yang paling dikutuk oleh umat muslim sedunia.Dalam Festival Urs di India yang diadakan tahunan, para pengunjung yang mencapai sekitar 70.000 orang selalu mengutuk beragam tindakan terorisme di kolong langit (halaman 215). Hal serupa dilakukan oleh kalangan muslim lain di penjuru dunia, sebagai penegasan bahwa terorisme atau tindakan menyakiti, bahkan membantai orang lain, bukan berasal dari Islam.

Pada prinsipnya, agama-agama di dunia tak henti memromosikan pentingnya toleransi.Ada banyak organisasi keagamaan maupun lintas keyakinan yang aktif menjalankan gerakan kampanye toleransi keberagaman.Tujuannya adalah memupuk rasa kebersamaan dan memupus nyinyir pada agama yang berbeda.Bahwa kalaupun tidak bersepakat pada hal-hal tertentu, semua orang pasti setuju pada nilai universal dari kedamaian, kemanusiaan, dan kebersamaan.

Di sisi lain, organisasi keagamaan di Indonesia, yang lahir dan asli terbentuk melalui kearifan lokal nusantara, selalu berusaha merekatkan persatuan dalam kebinekaan. Walau di pusaran konstelasi politik dan sosial belakangan yang begitu gaduh, pekerjaan ini tentu tidak mudah. Energi yang banyak tentu diperlukan secara mutlak.Termasuk untuk bersabar, menghadapi pihak-pihak yang kerap emosional melihat keadaan.Pada bagian lain, harus selalu diiringi rasa syukur, karena hidup di Indonesia telah memberi kebebasan dalam mengimplementasikan keyakinanan beribadah.

\section{KESIMPULAN}

Di media barat, stereotip yang terbangun terhadap muslim adalah kesan radikal yang kerap melakukan kekerasan dan anti perdamaian. Muslim kerap dianggap sebagai penganut Islam konservatif dan di sisi lain, di aspek militer misalnya, muslim adalah golongan yang lemah sementara Barat dipersepsikan superior. Meski demikian, belakangan ini, dengan makin terbukanya akses informasi, pandangan yang 
sedemikian rumit mulai tergerus.Apalagi, banyak penulis-penulis Barat yang mulai membuat ulasan pembelaan terhadap Islam.Dengan memberikan pandangan positif berikut argumen yang dapat dipertanggungjawabkan secara ilmiah, melalui bukubuku atau literatur yang ditulis secara objektif.

Pembelaan yang dimaksud antara lain dilakukan dengan menunjukkan fakta bahwa Islam bukan agama yang identik dengan kekerasan dan anti perdamaian. Justri sebaliknya, Islam membawa misi kesejahteraan bagi seluruh makhluk di muka bumi.Islam juga bukan agama yang konservatif.Sebaliknya, Islam peduli dengan modernitas dengan tetap menjaga esensi dari ajaran pokok.Semisal, Islam menggunakan teknologi dalam melakukan dakwah dan penyebaran agama.Bila terjadi perbedaan, toleransi tetap dikedepankan.Bukan hanya menggunakan senjata dan anti kompromi atau anti dialog.

Islam bukan agama yang lemah.Termasuk, dari sisi militer.Itu dibuktikan dengan penyebaran agama di masa lalu yang "terpaksa" menitikberatkan dalam pertempuran.Jadi, di masa lalu, kekuatan militer Islam tergolong superior. Di masa kini pun, negara-negara Islam tercatat memiliki armada yang baik. Contohnya, Iran yang sampai saat ini memiliki program nuklir yang dikhawatirkan oleh banyak negara lain.

\section{REFERENSI}

Akyol, Mustafa. Islam Tanpa Ekstrimisme. Jakarta: Elex Media Komputindo, 2014

Armstrong, Karen, dkk. Islamofobia. Bandung: Mizan, 2018

Benny, H. Semiotika dan Dinamika Sosial Budaya. Yogyakarta: Jalasutra, 2011

Burdah, Ibnu. Islam Kontemporer, Revolusi dan Demokrasi. Malang: Intrans Publishing, 2014

Eriyanto.Analisis Wacana, Pengantar Analisis Teks Media. Yogyakarta: Lkis, 2005

Faris.Representasi Kyai Ahmad Dahlan sebagai Tokoh Pembaharuan Islam dan Film "Sang Pencerah", Tesis di Universitas Airlangga Surabaya, 2012

Foucault, Michael. Discipline and Punish. Harmondsworth: Penguin, 1979

Hall, Stuart. Representation: Cultural Representatuons and Sygnifying Practices. London: Sage Publications Ltd, 1997 
Halliday., M.A.K. dan Ruqaiya Hasan. Bahasa, Konteks, dan Teks, Aspek-Aspek bahasan dalam Pandangan Semiotik Sosial, Yogyakarta: Gadjahmada University Press, 1994

Ida, Rachma. Metode Penelitian Kajian Media dan Budaya.Surabaya:AUP, 2011

Khadiri, E Churyha.Peradaban Islam yang Terlupakan, Yogyakarta: Araska, 2015

Majid, Anouar. Islam and America. Plymouth: Rowman \& Littlefield Publishers. Inc, 2012

Rauf, Imam Feisal Abdul. Islam Amerika, alih bahasa: Zulkarnaen Ishak, Bandung: Mizan, 2012

Ridouani, Driss. The Representation of Arabs and Muslims in Western Media. Barcelona: Revista Universitaria de Treballs Academics, 2011

Said, Edward W. Orientalisme, Yogyakarta: Pustaka Pelajar. Terjemahan dari buku Orientalism (1978), New York, Vintage Books, 2010

Sobur, Alex. Analisis Teks Media: Sebuah Pengantar Analisis Wacana, Analisis Semiotik dan Analisis Framing. Bandung: Remaja Rosdakarya, 2004

Shihab, QuraisH. Islam Universal, ed: Isep Abdul Malik\& Hendrianto Attan. Yogyakarta: Pustaka Pelajar, 2007

Thohari, Chamim, 2011, Konstruksi Pemikiran Quraish Shihab tentang Jilbab, Jurnal UMM Volume 14 Januari-Juni 2011

Wormser, Richard. American Islam: Growing Up Muslim in America. New York: Bloomsbury Publishing, 2002 